\title{
Exploring the moderating effects of absorptive capacity on the relationship between social networks and innovation*
}

\author{
Branka Ahlin, Mateja Drnovšek, Robert D. Hisrich ${ }^{* *}$
}

Although networks in prior research have been highlighted as a remedy to resource constraints experienced by smaller firms, little attention has been paid to understanding mechanisms through which smaller firms benefit from networks for effective innovation performance. In this paper we develop a conceptual model of direct and moderated network effects on a firm's innovation. We test this model on a large sample of small and medium-sized firms from a posttransitional and developed economy. We show that absorptive capacity moderates the relationship between networks and innovation outcomes, but with some country level variations. The implications of these results in relation to entrepreneurship theory and practice are discussed.

Obwohl Netzwerke bereits in früheren Forschungsarbeiten als probates Mittel gegen die Ressourcenknappheit in kleineren Unternehmen identifiziert wurden, hat man bis dato wenig Mühe darauf verwendet, die Mechanismen zu untersuchen, durch die kleinere Firmen, die ihre eigene Innovationsleistung steigern möchten, von Netzwerken profitieren. Wir entwickeln ein konzeptuelles Modell, das die direkten und indirekten Bezüge zwischen Netzwerken und der Innovationsleistung eines Unternehmens darstellt. Wir überprüfen das Modell mittels einer großen Stichprobe von kleinen und mittelständischen Unternehmen in einer durch die Transformation geprägten und einer entwickelten Volkswirtschaft. Wir zeigen, dass die absorptive capacity einen moderierenden Einfluss auf die dynamische Beziehung zwischen Netzwerken und Innovationsergebnissen hat, jedoch mit länderspezifischen Unterschieden. Die Bedeutung dieser Ergebnisse für die Unternehmenstheorie und -praxis wird diskutiert.

Keywords: Absorptive capacity; entrepreneur networks; innovation, moderating effect, SMEs, cross-cultural (JEL: L14, L26)

\footnotetext{
* Manuscript received: 11.2.13, accepted: 10.7.13 (1 revision)

** Branka Ahlin, Msc., researcher, Faculty of Economics, University in Ljubljana. Main research interest: analyzing various individual and firm level determinants of innovation performance of smaller and medium sized firms. E-mail: branka.ahlin@gmail.com

Mateja Drnovšek, Associate Professor, Faculty of Economics, University in Ljubljana. Main research interests: cognitive and emotional aspects of entrepreneurship and their influence on formation of entrepreneurial intentions, new venture creation and overall entrepreneurial effectiveness. Corresponding address: mateja.drnovsek@ef.uni-lj.si

Robert D. Hisrich, Garvin Professor of Global Entrepreneurship and Director of the Walker Center for Global Entrepreneurship at Thunderbird School of Global Management. Main research interests: emerging markets, innovation, technology transfer. E-mail: robert.hisrich@thunderbird.edu
} 


\section{Introduction}

Entrepreneurs exploiting innovation are seen as facilitators of regional dynamism (Audretsch et al. 2006), employment (Huggins/Williams 2012), and overall economic development (Anokhin et al. 2008). Since there is no general consensus on the entire scope of innovation determinants (Becheikh et al. 2006), there is no universal recipe for success in innovation (Bullinger et al. 2004). Yet, what is currently agreed upon is that the most successful innovators invest in the breadth of accumulated knowledge and absorb information from all kinds of sources - not just internal, but also all available external (Murovec/Prodan 2009:859). Relatedly, "absorptive capacity" refers to recognizing the value of new external knowledge and information, and assimilating and utilizing such knowledge for commercial ends (Cohen/Levinthal 1990). Entrepreneurial networks can provide many benefits in the form of novel information and accessing to diverse pools of information sources (Granovetter 1973), knowledge transfer (Tomlinson 2010), access to customers and suppliers (Brüderl/Preisendörfer 1998), advice and experiential learning, referral trust, and solidarity by a third party (Zhou et al. 2007). The dominant view in the literature is that through social networks firms share knowledge that can improve their capacities for innovation (Molina-Morales/Mas-Verdu 2008), which leads to greater levels of both product and process innovations (Tomlinson 2010) and creates sustainable competitive advantage for firms (Hervas-Oliver et al. 2012).

Previous research has focused on organizational networks when examining their impact on SME innovation outcomes (e.g. Jørgensen/Ulhøi 2010; Leick 2011). These findings have progressed our understanding of the role of organizational networks in maintaining competitive advantage in the face of hyper-competition confronting firms today (Jørgensen/Ulhøi 2010). There is a parallel view that personal networks of an entrepreneur may be an even more important factor than organizational networks in affecting performance (e.g. Watson 2007; Witt 2004). Personal networks of individual entrepreneurs in SMEs are seen as the basis to formation of broader social networks (e.g. inter-firm networks) (Xiangyang et al. 2010). Because many entrepreneurs are the only ones involved in the innovation process in small firms (North/Smallbone 2000), understanding the role of personal networks in the process is important.

In this paper we make the following contributions. First, we explore mechanisms through which entrepreneurs' personal networks directly and indirectly impact an SME's innovation. Although several researchers (e.g. Hervas-Oliver et al. 2012) emphasize that internal capabilities enhance the firm's ability to assimilate and exploit external knowledge, a question of how smaller firms build and grow capacities for innovation based on the benefits from networks remains unanswered. Because networks can offer SMEs free flows of new ideas, researchers (e.g. Brüderl/Preisendörfer 1998) emphasize that networks will improve success only if the entrepreneur makes use of them. This suggests that mechanisms 
through which SMEs develop network-related resources may not be linear, and other factors may be intervening in determining the relationship between network co-operation and innovation. Our first contribution is to the literature on the role of personal networks in entrepreneurship.

Second, we explore the nuanced effects of absorptive capacity in small and medium-sized firms. In the context of larger organizations, absorptive capacity was shown to be a key internal capacity of a firm that impacts how effectively external information and knowledge are adopted (e.g. Escribano et al. 2009; Kotabe et al. 2011). In entrepreneurship research, absorptive capacity was associated with SMEs' capabilities to collaborate with external partners (i.e. universities and technology transfer centres) (e.g. Muscio 2007), use of new production technologies (e.g. Julien et al. 2004), and properties of knowledge (e.g. Wang/ Han 2011). Given that prior research pointed to the intervening role that absorptive capacity may have in the effectiveness of use of external resources, we explore its role in directing mechanisms through which SMEs use resources from personal networks of entrepreneurs.

Finally, researchers (e.g. Engelen et al. 2009) propose that from a theoretical perspective, cross-cultural studies can advance entrepreneurship research by helping to distinguish between relationships that are universally valid and those that are culturally dependent. By examining context specificities in an empirical test of the absorptive capacity's moderating role in the samples of small and medium-sized firms from a developed market economy and smaller transition economy, we contribute to the understanding in this area.

\section{Theory and hypotheses}

Our study builds on the foundations of a "network approach" to entrepreneurship (Aldrich/Zimmer 1986), and a "network success hypothesis" (Brüderl/ Preisendörfer 1998). This hypothesis suggests that those entrepreneurs who can refer to broad and diverse social networks, and who receive some support from their networks are more successful. According to the personal network perspective, entrepreneurs use these networks to obtain information that is valuable to the business. These networks are built from weak and strong ties that together form access to diverse information sources. In order to benefit from the information that is extracted from networks, firms need to have absorptive capacity to capitalize on knowledge acquisition and facilitate organizational learning (Kotabe et al. 2011).

\subsection{Entrepreneur's personal networks and innovation}

Building on the prior literature outlined above, we propose that personal networks enhance the innovation performance of SMEs. Prior studies (e.g. Greve/ Salaff 2003) suggest that entrepreneurs make their business decisions within social structures. These studies also identified three pathways through which en- 
trepreneurs improve their business success (Brüderl/Preisendörfer 1998). The first pathway includes gaining access to valuable and reliable information through the network of social relations and social contacts. The focus of this mechanism is on the role of the weak ties of entrepreneurs - weak ties provide particularly valuable information because this information often comes from remote parts of the social system (Granovetter 1973). Second, network contacts are direct channels to potential customers and suppliers. This benefit is further leveraged through a snowball effect (Bögenhold 1989) - friends and acquaintances of the first customer might spread information on the new firm via their own networks. The third pathway includes access to information important for strengthening financial resources of a growing venture. Informal credits received from relatives or acquaintances are specifically important in the start-up phase, while the credit-raising function of social relations is more important in the growth phases of a venture. Finally, taking a firm's level perspective Lechner, Dowling and Welpe (2006) examine the role of the network relational mix on the development of the entrepreneurial firm to find that the relational mix of networks is a more important factor for explaining firm development than sheer network size.

Based on prior research findings, we expect that entrepreneurs' networks will be related to SMEs' innovation because they secure access to information important for innovation, financial resources, and potential costumers of innovative products and services. Furthermore, findings from prior research suggest analysing innovation outcomes by differentiating between product and process innovation. First, researchers (e.g. Rammer et al. 2009) emphasize that innovation activities can target both types; there are many successful process innovations that are not related to product innovation success, particularly with regard to costsaving process innovation. Second, we followed prior arguments (e.g. Ornaghi 2006) that the magnitude and pervasiveness of spill-over effects for product and process R\&D are likely to be different. For example, Nieto and Santamaria (2010) found that benefits from technological collaborating of SMEs with suppliers and clients are more significant for product than process innovations. Meanwhile, Ornaghi (2006) emphasizes that imitation of a product innovation can be achieved through reverse engineering while diffusion of process innovation may require more sophisticated channels, such as industrial espionage or recruitment of engineers and experts of rival firms. Third, researchers (e.g. Damanpour 2010; Kraft 1990) emphasize that the validity of the assumption that product and process innovations are determined differently by the same antecedents has not been fully examined. Although both of them could lead to an increase in the output produced by the firm, the forces behind this output expansion are quite different and deserve a separate analysis (Ornaghi 2006). We respond to these calls by empirically testing the influence of entrepreneur's network separately for product and process innovation. This leads us to propose the following hypothesis: 
Hypothesis la: There is a positive relationship between an entrepreneur's personal network and product innovation.

Hypothesis 1b: There is a positive relationship between an entrepreneur's personal network and process innovation.

\subsection{Absorptive capacity and innovation}

The concept of absorptive capacity was first defined as a firm's "ability to recognize the value of new information, assimilate it, and apply it to commercial ends" (Cohen/Levinthal 1990:128). In their early view of absorptive capacity Cohen and Levinthal (1989) develop a static model to explore the effects of the ease of learning and the character of extramural knowledge on investment in absorptive capacity and, in turn, R\&D. Their model considers the basic sources of technological knowledge utilised by a firm: the firm's own R\&D, the knowledge which originates with its competitors' R\&D spillovers, and the knowledge which originates outside the industry (Cohen/Levinthal 1989). Cohen and Levinthal (1994) also argue that absorptive capacity not only enables a firm to exploit new extramural knowledge, but also to predict more accurately the nature of future technological advances.

Zahra and George (2002) redefine the concept by differentiating between potential absorptive capacity (a firm's ability to value and acquire external knowledge, which does not guarantee the exploitation of this knowledge) and realized absorptive capacity (a firm's ability to exploit externally generated knowledge, to transform and commercially apply knowledge that creates firm value) (Zahra/George 2002). Jansen, Van Den Bosch and Volberda (2005) explored how different organizational antecedents affect aspects of absorptive capacity. They identified differing effects for potential and realized components of absorptive capacity. The results indicate that organizational mechanisms associated with coordination capabilities (cross-functional interfaces, participation in decision making, and job rotation) primarily enhance a unit's potential absorptive capacity. Organizational mechanisms associated with socialization capabilities (connectedness and socialization tactics) primarily increase a unit's realized absorptive capacity. Later, Volberda, Foss and Lyles (2010) develop an integrative model that identifies the multi-level antecedents, process dimensions, and outcomes of absorptive capacity as well as the contextual factors that affect absorptive capacity and suggested that further research should focus on the impact of certain intra-organizational antecedents, such as structures and informal networks; and better understanding of how inter-organizational networks influence absorptive capacity.

Taken altogether, absorptive capacity is often seen as a complementary capability to other capabilities of a firm (Pinkse et al. 2010:163) and researchers (e.g. Lenox/King 2004; Spithoven et al. 2010) have shown that absorptive capacity can be explored and developed through investing in the R\&D capacities of a 
firm and other activities. Building from the theory of absorptive capacity, studies (e.g. Cohen/Levinthal 1990; Zahra/George 2002) propose that the strength of absorptive capacity in a firm depends upon breadth of prior knowledge in a firm and knowledge diversity. This explains why absorptive capacity beneficially impacts important organizational outcomes, such as innovation. Along with strengthening absorptive capacity resource, diverse knowledge also boosts individuals" capacities to make "novel associations and linkages" (Cohen/Levinthal 1990:131). Diversity is instrumental in innovation processes since evidence shows that most successfully commercialized innovations are an outgrowth of making new associations and/or recombining existing ideas (Dahlander/Gann 2010). For example, Apple's iPod was not the first digital-music player on the market. Similarly, the iPhone was not the first smart phone. Yet, Apple was able to launch these products as innovations by recombining existing technological solutions and by having their devices more functional and appealing.

Prior research suggests that a firm's absorptive capacity oftentimes moderates the relationship between different external bases of knowledge and innovation. Julien et al. (2004) found that the impact of weak signal networks on new production technology penetration appears to be greater in firms with a greater absorptive capacity, where absorptive capacity was measured by the number of higher education graduates (college and university) and the number of people involved in formal R\&D. Kotabe and colleagues (2011) focused on realized absorptive capacity by examining how managers' ties and organizational realized absorptive capacity affect firms' new product market performance. The results of their study indicate that knowledge acquisition can only enhance new product market performance with the presence of realized absorptive capacity. They conclude that managers' decisions on knowledge acquisition from external sources may not increase firms' new product market performance; instead, managerial prowess in integrating and transforming knowledge becomes paramount in enhancing new product market performance (Kotabe et al. 2011).

Several studies in entrepreneurship elaborate on the role of networks in smaller ventures. Given that small firms extensively use external networking to overcome the liability of smallness in knowledge creation (e.g. Havnes/Senneseth 2001:293); a body of literature explores how networks contribute to the development of intangible resources that are important for innovation. First, in exploring the specific effects of external networking, some studies (e.g. Shan et al. 1994) emphasize that the number of co-operative ties leverages network benefits because co-operative ties provide firms with (potentially) greater access to external resources (Tomlinson 2010:764). In particular, Shan et al. (1994) found that the innovative output (measured with patent counts) of start-up firms was positively associated with the number of formal co-operative ties these companies held with more established firms. Bougrain and Haudeville (2002) and Muscio (2007:655) suggest that SMEs need to develop their internal capacities 
by training and recruiting personnel in order to assimilate and diffuse information. In examining such "internal capacities" Escribano et al. (2009:97) found evidence for the positive moderating effect of absorptive capacity - firms that have higher levels of absorptive capacity are more efficient in managing external knowledge flows, which in turn stimulate innovative outcomes. Taken altogether, the extent to which a firm can benefit from external knowledge depends on its capacities to absorb and exploit it (Zahra/Hayton 2008:199). This leads us to the following hypothesis:

Hypothesis 2a: The interaction of an entrepreneur's networks and the realized absorptive capacity of an SME has a positive effect on product innovation.

Hypothesis 2b: The interaction of an entrepreneur's networks and the realized absorptive capacity of an SME E has a positive effect on process innovation.

The proposed relationships are depicted in Figure 1.

Figure 1: Moderating effect of realized absorptive capacity

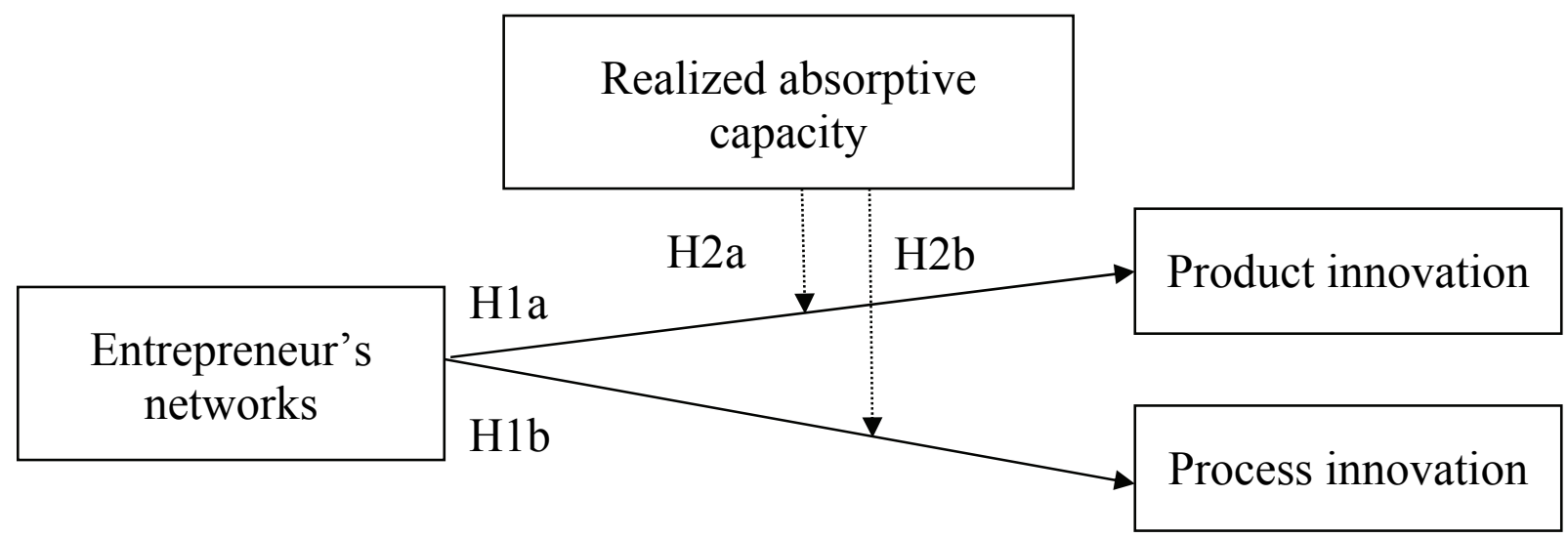

Control variables

Gender
Prev. experience
Prev. ex in industry
Firm size
Firm age
Industry

\section{Methods}

To test the hypothesis proposed above, a questionnaire-based survey was conducted on two samples of entrepreneurs. In the following we discuss our sample choice, questionnaire development, data collection, and analytical procedures. 


\subsection{Data}

Hypotheses were tested using empirical data from two countries: the United States and Slovenia. The decision to use empirical data sets from two contrasting environments is aligned with current research needs in the entrepreneurship literature. Slovenia differs notably from the U.S. in terms of its entrepreneurship practice, and the level of economic development and size, which implies differences in the entrepreneurial contexts between these countries.

The data was collected via two mail surveys in the following time periods: between May and June 2011 in Slovenia and between September and October 2011 in the U.S. We followed Dillman's (2007) total design method. Using the postal service, we sent out mailing packages containing a personalized cover letter, a questionnaire, and a postage-paid return envelope to 4,000 entrepreneurs in the U.S. and 3,400 entrepreneurs in Slovenia. We used the Reference USA research database to randomly select firm addresses in the U.S. and the business directory of the Republic of Slovenia (PIRS) to generate a random sample in Slovenia. Of the 3,940 delivered surveys in the U.S., we received 314 useful surveys; two questionnaires were excluded due to the more than $20 \%$ missing data. This represents an 8\% valid response rate. From 3,376 delivered questionnaires in Slovenia, we received 913 completed surveys (five questionnaires were excluded since they had a high proportion of missing data). This represents a $27 \%$ valid response rate. Due to the difference in response rate between countries we have randomly selected 400 cases out of the Slovenian sample to create two matching samples in terms of response numbers. The responding small ventures operate in a wide variety of industries (e.g. manufacturing, professional, scientific and technical, information and communication, construction) and in both samples the sectoral structure is somewhat representative of the sectoral value-add as a share (\%) of a nation's GDP.

\subsection{Measures}

To measure the constructs in our model, we adopted existing measures from the literature.

Realized Absorptive Capacity. We measured a firm's realized absorptive capacity with a scale proposed by Kotabe et al. (2011). Nine scale items assess a firm's knowledge, transformation, and exploitation. Respondents were asked to indicate their degree of certainty on a seven-point Likert scale ranging from 1 ("strongly disagree") to 7 ("strongly agree"), how strongly they agree or disagree with the firm's capabilities such as: capability to adapt the acquired new knowledge to fit the firm's development needs, develop a new product/service by using assimilated new knowledge, develop new applications by applying assimilated new knowledge, and find alternative uses of assimilated new knowledge. 
Entrepreneur's Networks. To assess an entrepreneur's network, we used measurement items from Prodan and Drnovšek's (2010) survey. In their survey the first two items were originally adopted from Greve (1995) and assessed the average number of hours per week the respondent spent maintaining contacts (e.g., face-to-face, e-mail, telephone) with people with whom he/she discussed business matters (e.g., commercialization, marketing, finance), the average number of hours per week the respondent spent developing new contacts with people to discuss business matters. The third item was developed by Renzulli et al. (2000) and covers the total number of people with whom the respondent discussed business matters during the previous week.

Product and Process Innovation Output. We differentiated between product and process innovation, as it was the case in several prior studies (e.g. JiménezJiménez/Sanz-Valle 2011; Murovec/Prodan 2009; Rammer et al. 2009; Yang et al. 2009). Both dimensions of innovation were measured with three items. Items for product innovation were drawn from Yang et al. (2009) and include the number of a firm's new products that are first-to-market (or early market entrants), the number of new products/services a firm has introduced to the market, and the speed of the firm's new product/services development. Items for process innovation were drawn from Jiménez-Jiménez and Sanz-Valle (2011) and include the number of changes in processes introduced, a pioneering disposition to introduce new processes, and clever responses to new processes introduced by others companies in the same sector.

Control Variables. Since an SME's innovation can be influenced by other firm level characteristics and entrepreneur level characteristics, we controlled for the following variables. At the individual level, we controlled for the entrepreneurs' gender, previous experience, and previous experiences in their current industry. While at the firm level, we controlled for firm size, firm age, and industry type. The entrepreneurs' previous experience was measured using their total number of years of employment, and the entrepreneur's previous experience in their current industry was measured using the number of years of employment in their current industry. Firm size was measured by the number of current employees in the firm, and firm age was measured as the number of years since the firm had been established. Industry type was coded as ' 0 ' for manufacturing, and ' 1 ' otherwise.

\subsection{Data analysis}

We controlled for common method bias since data was collected via selfreported questionnaires from a single respondent. As a precaution, we undertook steps during the survey development. Anonymity of respondents was ensured; additionally, we randomised the order of the items by putting the items in reverse order (Huang et al. 2012). Finally, Harman's one-factor test was conducted and indicated that common method bias was found to be unlikely to be a seri- 
ous problem in the data (Podsakoff et al. 2003). Before testing for a significant relationship in the model, it needed to be demonstrated that the measurement model had a satisfactory level of validity and reliability (Fornell/Larcker 1981:45). The construct reliability was assessed by calculating Cronbach's alpha's and composite reliability. As Table 1 shows, both reliability measures were above 0.70 (Diamantopoulos/Siguaw 2009) in each country, which is an acceptable level of reliability.

Table 1: Measurement scales: number of items, sources of items, reliability, and variance extracted

\begin{tabular}{|c|c|c|c|c|c|c|}
\hline \multirow{2}{*}{ Construct } & \multirow{2}{*}{$\begin{array}{l}\text { Num. } \\
\text { of } \\
\text { items }\end{array}$} & \multirow{2}{*}{ Source } & \multicolumn{2}{|c|}{ Cronbach $\alpha$} & \multicolumn{2}{|c|}{$\begin{array}{l}\text { Composite } \\
\text { reliability }\end{array}$} \\
\hline & & & US & Slovenia & US & Slovenia \\
\hline $\begin{array}{l}\text { Realized } \\
\text { absorptive } \\
\text { capacity }\end{array}$ & 6 & $\begin{array}{l}\text { Kotabe et al. } \\
\quad(2011)\end{array}$ & 0.90 & 0.93 & 0.89 & 0.93 \\
\hline $\begin{array}{l}\text { Entrepreneur's } \\
\text { networks }\end{array}$ & 3 & $\begin{array}{c}\text { Prodan/Drnovšek } \\
\text { (2010) }\end{array}$ & 0.84 & 0.81 & 0.86 & 0.83 \\
\hline $\begin{array}{l}\text { Product } \\
\text { innovation }\end{array}$ & 3 & Yang et al. (2009) & 0.83 & 0.84 & 0.87 & 0.85 \\
\hline $\begin{array}{l}\text { Process } \\
\text { innovation }\end{array}$ & 3 & $\begin{array}{l}\text { Jiménez-Jiménez/ } \\
\text { Sanz-Valle (2011) }\end{array}$ & 0.87 & 0.84 & 0.85 & 0.86 \\
\hline
\end{tabular}

An exploratory factor analysis was performed using the SPSS Version 16.0 for Windows and using the Maximum Likelihood extraction method and Direct Oblimin rotation. A confirmatory factor analysis was also undertaken, since it is a useful method to test the reliability and validity of constructs across different countries (Craig/Douglas 2005). The confirmatory factor analysis was performed on each of the constructs individually using Lisrel 8.51 to test whether all the scales in both samples met the requirements of unidimensionality, and discriminant validity (Fornell/Larcker 1981).

To examine the potential moderating effect of the realized absorptive capacity on the relationship between the entrepreneur's network and innovation, we conducted a series of hierarchical regression analyses following Aiken and West (1991) and Cohen et al. (2003). We ran separate regression analyses for the four models for each country and for each dimension of innovation. The descriptive statistics and inter-correlations of the variables that were used in the study are indicated in Table 2. 


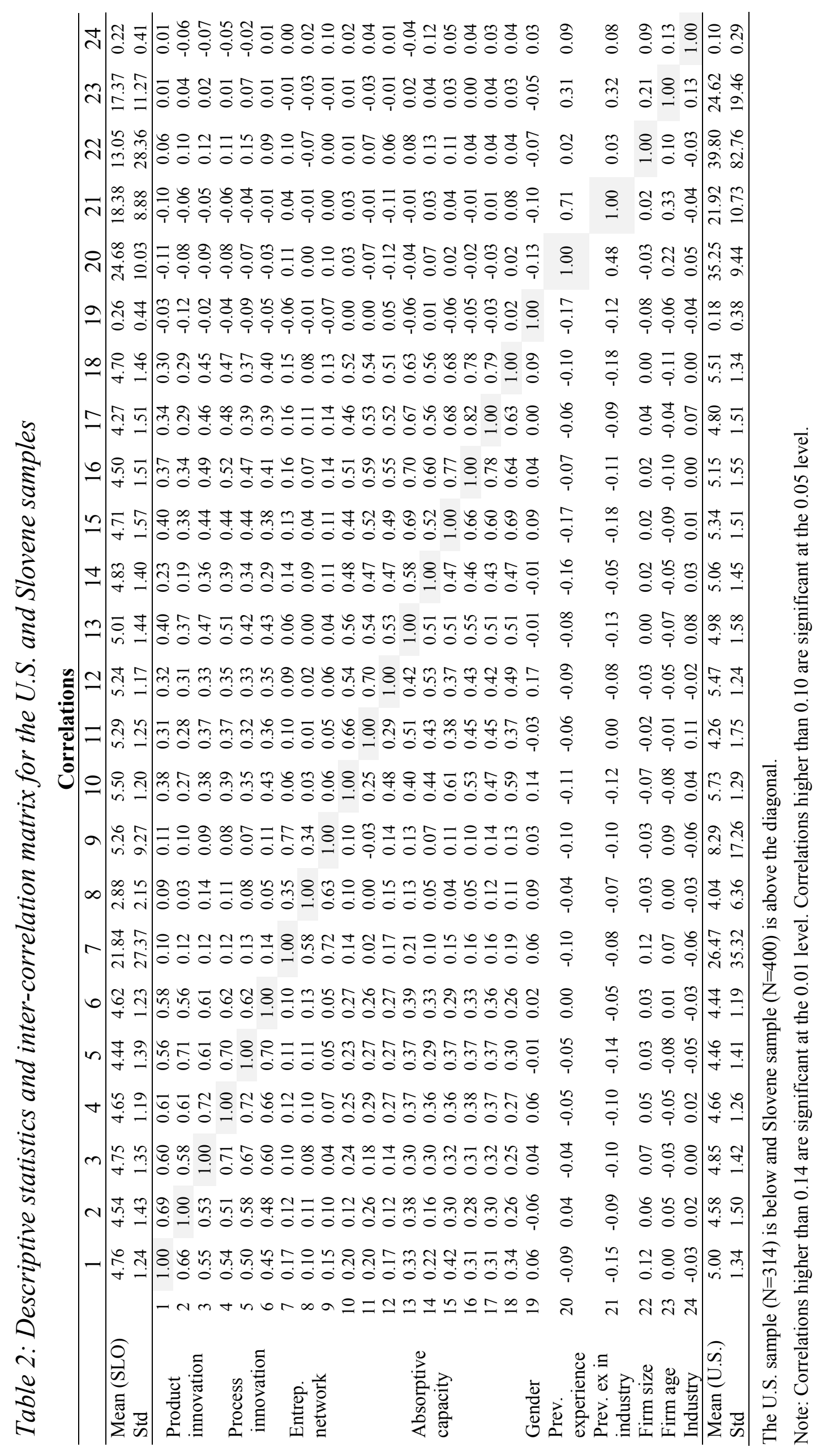




\section{Results}

Table 3 indicates the results of moderated regressions for product and process innovations. The base model (Model I) showed that firm size had a significant positive impact on product innovations for both samples, and previous experiences in their current industry was significant as a control variable in the U.S. sample for product innovation. Neither entrepreneur's gender, previous workrelated experiences, firm age, nor industry had a significant influence on the product and process innovation for either the base model or any of the subsequent models proposed.

Model II included the entrepreneur's personal network. We predicted that an entrepreneur's network is positively related to product innovation (Hypothesis 1a) and to process innovation (Hypothesis 1b). The results (see Table 3) showed that the beta coefficients were positive and statistically significant for product (U.S.: $\beta=0.25, p<0.01$, Slovenia: $\beta=0.18, p<0.01$ ) for both samples, while for process innovation (U.S.: n.s., Slovenia: $\beta=0.15, p<0.001$ ) only for the Slovene sample. This provides full support to hypothesis 1a and partial support to hypothesis $1 b$.

In Model III we added absorptive capacity. Although not hypothesized, this model showed that absorptive capacity was positively related to both types of innovation in both samples. This model contributed an increase in the explanation of variance, over and above the base model for both dimensions of innovation. In addition, when we added a variable of absorptive capacity the direct influence of the entrepreneur's network on process innovation outcomes was no longer significant in both samples, while the link to product innovation was significant in the Slovene sample. This supports our argument that the relationship between an entrepreneur's network and innovation outcome should not be seen as a straightforward main effect.

Finally, the full model incorporated the moderating effect of realized absorptive capacity. Incorporating this variable improved the coefficient $\mathrm{R}^{2}$ for the U.S. model by $2 \%$ for both dimensions of innovation (to 0.12 for product innovation and 0.10 for process innovation). A moderator hypothesis is supported if the interaction is significant, regardless of any main effects (Baron/Kenny 1986). Hypothesis 2 a postulates that realized absorptive capacity has a positive moderating effect on the linkage between an entrepreneur's networks and product innovation. The results of the hierarchical regression analysis (see Table 3) shows that our interaction term (Soc x AC) was positive and significant for the U.S. sample, while the beta coefficient for the Slovene sample was negative and not significant. Hypothesis $2 \mathrm{a}$ was partially supported. We display the nature of the moderation for the U.S. sample following recommendation of Aiken and West (1991) (see Figure 2). For higher absorptive capacity the relationship between 
social network and product innovation was stronger, while the relationship was weaker for lower absorptive capacity.

Figure 2: Moderating effects of absorptive capacity and entrepreneur's network on product innovation for U.S. sample

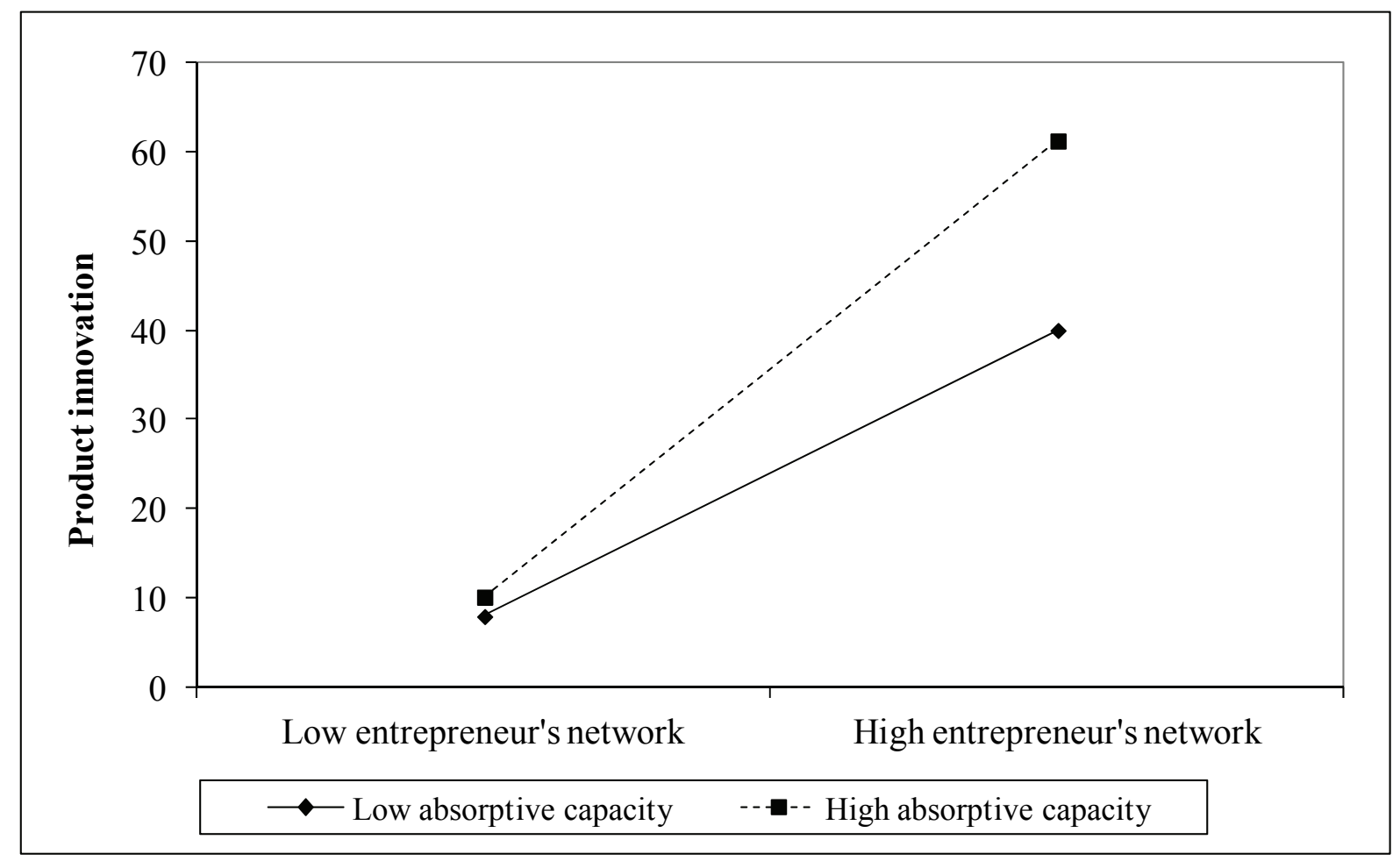

Hypothesis $2 \mathrm{~b}$ postulates that realized absorptive capacity has a positive moderating effect on the relationship between an entrepreneur's networks and process innovation. The results of the hierarchical regression analysis indicate partial support for Hypothesis $2 b$. The moderating effect of absorptive capacity through an entrepreneur's networks on process innovation was positive and significant for the U.S. sample, while the beta coefficient in the Slovene sample was nonsignificant. Hypothesis $2 \mathrm{~b}$ is partially supported. Moreover, Figure 3 demonstrates that the relationship between an entrepreneur's network and process innovation becomes more positive with higher levels of absorptive capacity than with lower levels for the U.S. sample. 
Figure 3: Moderating effects of absorptive capacity and entrepreneur's network on process innovation for U.S. sample

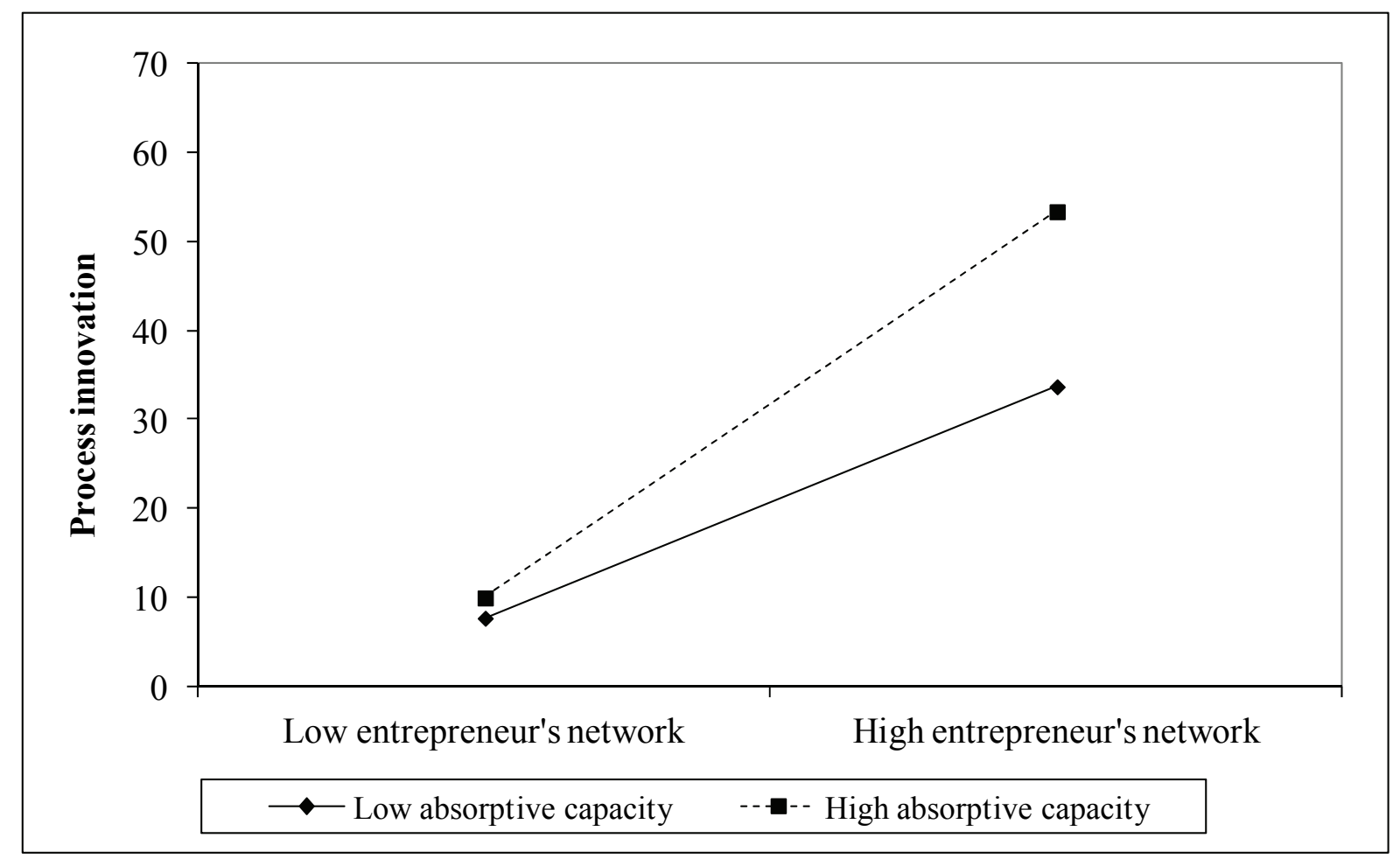

\section{Discussion and implications}

The results of this research contribute to the growing body of empirical research on entrepreneur networks and SME innovation. We built upon existing theoretical foundations and empirical evidence supporting the role of entrepreneurial networks and firms' absorptive capacity on the innovation of SMEs. This study was in line with the resurgence of interest in how regions can facilitate innovation by SMEs and thus contribute to economic development. In the following paragraphs, our contributions to studying entrepreneurial networks, absorptive capacity, and SMEs innovation are discussed. The primary contribution of our research shows that innovation of SMEs is positively associated with personal networks of entrepreneurs and that this relationship is strengthened by SMEs' absorptive capacity. Our results supported the hypothesized relationships in the U.S. sample while those relationships were not found significant in the Slovene sample. Understanding the mechanisms through which the effects of an entrepreneur's personal networks are translated to firm level outcomes has important implications for future research on networks and innovation, and for the efforts of entrepreneurs to capitalize on their network-related resources. So far, researchers have found that an entrepreneur's personal networks have an important positive influence on various firm outcomes such as venture growth (e.g. Lee/Tsang 2001) and performance (e.g. Kariv et al. 2009). 


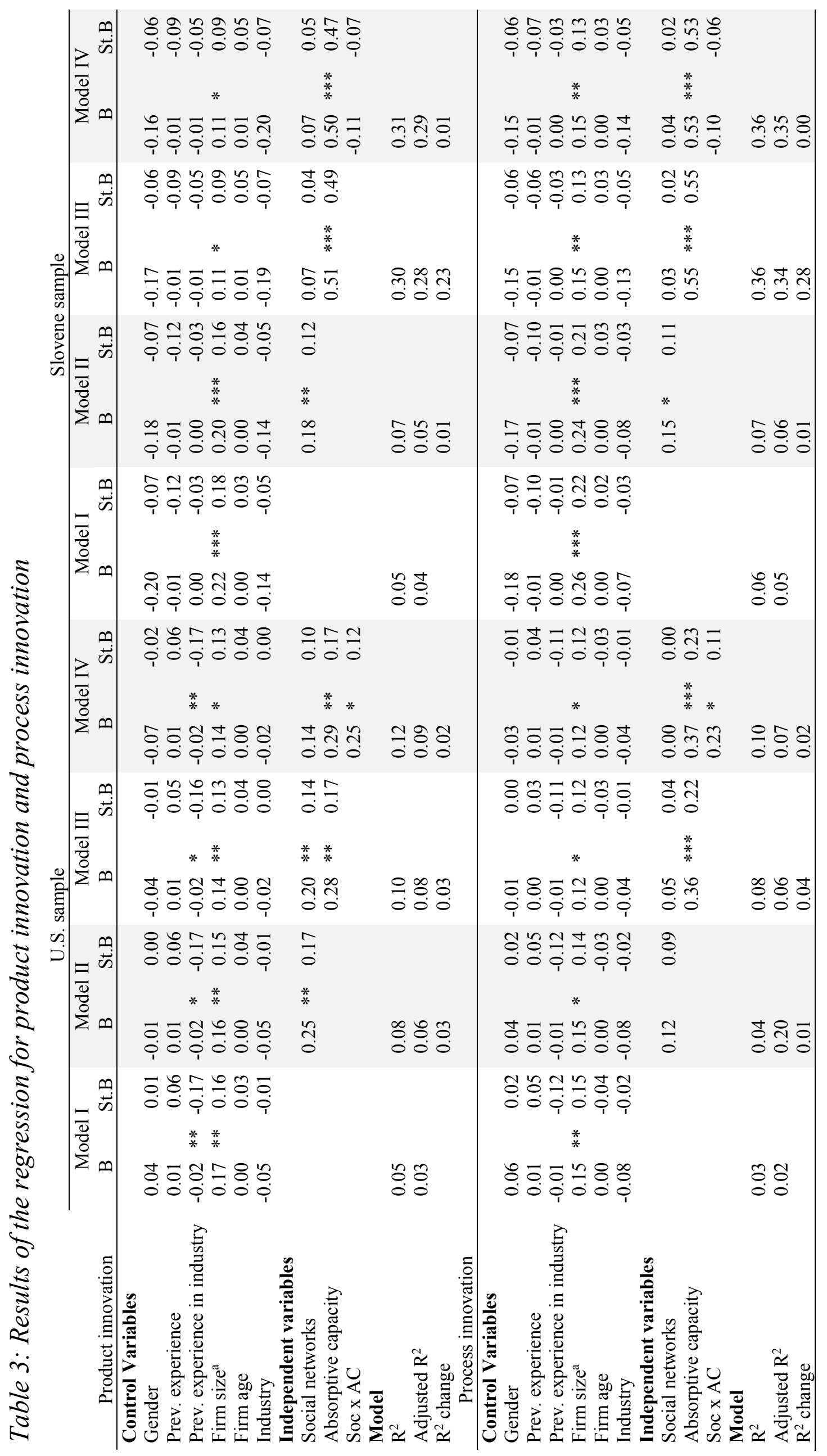




\subsection{Theoretical implications}

Our first contribution is to the growing body of literature examining the role of entrepreneurial networks in facilitating SME innovation. To date, prior studies have examined the impact of personal networks of entrepreneurs on important firm level-related outcomes, such as internationalization, performance, and innovation (e.g. Huang et al. 2012; Manolova et al. 2010). Our empirical findings are that the personal networks of entrepreneurs positively impact process and product innovation in contrasting economic environments, and further reinforce the "network success hypothesis" (Brüderl/Preisendörfer 1998). Perhaps more importantly, our findings shed light on when and how resources from personal networks positively impact innovation: when realized absorptive capacity is activated to promote learning from information and knowledge retrieved in networks. While the effects of absorptive capacity on entrepreneurial learning have been suggested previously (e.g. Escribano et al. 2009; Julien et al. 2004; Wang/ Han 2011), the specific moderating effect of realized absorptive capacity on the relationship between entrepreneurial networks and innovation output has not been empirically tested. The results of this study demonstrate that both an entrepreneur's networks and realized absorptive capacity are not only important factors to be considered, but also are factors that need to be matched in order to maximize innovation.

We also tested our model in two contrasting countries and our results indeed indicate variations between countries in terms of innovation determinants in companies. These country-level differences in our findings do not come as surprise; some prior studies highlighted differences in their findings due to cross-country samples (e.g. Greve/ Salaff 2003; Klyver et al. 2008). In our study, the moderating effect of realized absorptive capacity was found to be positively and significantly related to product and process innovation among SMEs in the United States. Since the primary objective of this study was not to compare differences between the two countries but to demonstrate a cross-cultural validity of the model, the tested model and the available data do not offer deep information about sustentative reasons behind those differences. However, we could hypothesize that many such differences can be attributed to the underlying reasons, such as the presence of support structures to SMEs networking activities, attitudes towards innovation and entrepreneurship in the general population, differences in economic histories, differences in the sophistication of organizational business strategies and practices, and other culture related differences. Indeed, prior research on national levels of entrepreneurial activity (e.g. Carree et al. 2007) suggested that entrepreneurial activity varied among countries because of differences in GDP and differences in the stage of economic development in regions within those countries. Further, during the time period when data was collected in Slovenia, its economy was in the middle of a recession period, which hit European markets more extensively than the U.S. economy. It seems that 
during such times firms are less inclined to innovate. This argument can be supported with the findings of a longitudinal study conducted by Parisi et al. (2006) among Italian firms. They found that more firms introduced innovations in the second wave, when the economy was expanding and investment was recovering, than in the first wave, when the Italian economy was in the middle of a recessionary period.

\subsection{Practical implications}

Our results suggest several practical implications for entrepreneurs and business practitioners. While entrepreneurs network were seen to be important, especially in the early phase of new venture establishment, our findings reinforce the essential role of personal networks within the life-cycle of a venture. Obviously entrepreneurs cannot do everything on their own. Different ties within an entrepreneur's network can provide knowledge diversity and help; however, this does not mean that just because an individual entrepreneur has a large network, that network resources can be effectively retrieved. Our findings reinforce the notion that the benefits of an entrepreneur's personal networks are related to the breadth and depth of contacts within such networks. Important advantages are associated with establishing internal structures in their firms (e.g. absorptive capacity) needed for more effective assimilation and exploitation of networkrelated resources. In developing their networks, prior studies show that it is better to develop networks based on firm priorities rather than the entrepreneur's social contacts (Manolova et al. 2010). Our findings also suggest that the higher the absorptive capacity of an SME, the greater the benefits from being exposed to diverse ties within the network. For instance, Jones and colleagues (2009) propose that to increase absorptive capacity, an entrepreneur needs to recognize what he/she does not know, and develop generative learning processes within the firm to facilitate problem-solving processes, and create internal procedures that convert tacit and individual knowledge to explicit and shared knowledge. On the other hand, Cohen and Levinthal (1990) emphasized that the intensity of a firm's effort is a key to development of an effective absorptive capacity. Similarly Baldwin, Magjuka and Loher (1991) accent that even though the organization may consist of individuals with high abilities to learn, "its ability to utilize the absorbed knowledge will be low if employees' motivation is low or absent". Therefore, entrepreneurs should apply specific human resource management practices oriented towards their employees' ability and motivation. Supporting evidence comes from the behavioural science literature (e.g. Libby 1993; O'Reilly Iii 1994), suggesting that both employees' ability and motivation are of importance for organizational behaviour.

Finally, fostering innovative entrepreneurship is an evergreen agenda among regional policy makers. The results of our study showed variations in innovation outputs between sampled countries. There have been significant efforts to identi- 
fy the characteristics of successful regions (de Jong/Freel 2010). Many countries have governmental programs or special agencies that try to foster collaboration in the form of consortiums, alliances, joint ventures, professional associations, or networks to generate higher levels of innovation and growth. Results of our study show the importance of absorptive capacity in the network-innovation link, suggesting that policies should aim to develop the firm's capabilities needed to assimilate and exploit knowledge; this is likely to be particularly important in areas where innovation resources are relatively scarce, such as transitioning economies and economies progressing among stages of development (de Jong/Freel 2010).

\subsection{Limitations and future research opportunities}

As with any study, there are several limitations to our research design. First, as in numerous previous empirical studies (e.g. Hmieleski/Corbett 2008; Lasagni 2012), measures in our analysis are based on self-reported data provided by entrepreneurs. Use of objective or observer-rated measures (Foo et al. 2009) reduces the potential impact of such bias. Furthermore, using empirical data collected with one method (survey) provides a problem for common method bias (Podsakoff et al. 2003). Although we conducted the most important statistical tests to identify the potential presence of common method bias and undertook the most important precautions during questionnaire development, future studies could profit from combining in their design empirical data from several sources. Further, despite a careful design of our conceptual model, we did not examine other potential moderators of the relationship between entrepreneur's networks and innovation aside from realized absorptive capacity. There may be other potential individual level variables that moderate the relationship between entrepreneur's network and innovation. For example, the results of Kickul and Walters's (2002) study show that one such personal attribute that serves as a critical link in determining whether the firm uses new opportunity information to develop and integrate e-innovations is the proactivity of the entrepreneur. Therefore, future studies may conceptualize and empirically test why and how proactivity moderates relationship between personal networks and innovation. Finally, the results show differences between countries. In the U.S. sample the moderating effect of realized absorptive capacity on product and process innovation was positive and statistically significant, while it was non-significant in the Slovene sample. Further research can provide further explanation by considering additional country-specific variables that determine SME innovation, such as Klyver et al. (2008) who examined the similarities and differences in networking practice among entrepreneurs in different countries.

\section{References}

Aiken, L.S./West, S.G. (1991): Multiple Regression: Testing and Interpreting Interactions. Thousand Oaks: Sage. 
Aldrich, H./Zimmer, C. (1986): Entrepreneurship through Social Networks, in: Sexton, D.L./Smilor, W. (Ed.): The Art and Science of Entrepreneurship. Cambridge, MA: Ballinger.

Anokhin, S./Grichnik, D./Hisrich, R.D. (2008): The Journey from Novice to Serial Entrepreneurship in China and Germany: Are the Drivers the Same?, in: Managing Global Transitions, 6, 2, 117-142.

Audretsch, D.B./Keilbach, M./Lehmann, E. (2006): Entrepreneurship and Economic Growth. Oxford: Oxford University Press.

Baldwin, T.T./Magjuka, R.J./Loher, B.T. (1991): The Perils of Participation: Effects of Choice of Training on Trainee Motivation and Learning, in: Personnel Psychology, 44, $1,51-65$.

Baron, R.M./Kenny, D.A. (1986): The Moderator-Mediator Variable Distinction in Social Psychological Research: Conceptual, Strategic, and Statistical Considerations, in: Journal of Personality and Social Psychology, 51, 6, 1173-1182.

Becheikh, N./Landry, R./Amara, N. (2006): Lessons from Innovation Empirical Studies in the Manufacturing Sector: A Systematic Review of the Literature from 1993-2003, in: Technovation, 26, 5-6, 644-664.

Bögenhold, D. (1989): Die Berufspassage in das Unternehmertum-Theoretische und empirische Befunde zum sozialen Prozeß von Firmengründungen, in: Zeitschrift für Soziologie, $18,4,263-281$.

Bougrain, F./Haudeville, B. (2002): Innovation, Collaboration and SMEs Internal Research Capacities, in: Research Policy, 31, 5, 735-747.

Brüderl, J./Preisendörfer, P. (1998): Network Support and the Success of Newly Founded Business, in: Small Business Economics, 10, 3, 213-225.

Bullinger, H.J./Auernhammer, K./Gomeringer, A. (2004): Managing Innovation Networks in the Knowledge-Driven Economy, in: International Journal of Production Research, 42, $17,3337-3353$.

Carree, M., et al. (2007): The Relationship between Economic Development and Business Ownership Revisited, in: Entrepreneurship and Regional Development, 19, 3, 281291.

Cohen, J. et al. (2003): Applied Multiple Regression/Correlation Analysis for the Behavioural Sciences. Mahaw: Lawrence Erlbaum Associates.

Cohen, W.M./Levinthal, D.A. (1989): Innovation and Learning: The Two Faces of R\&D, in: Economic Journal, 99, 397, 569-596.

Cohen, W.M./Levinthal, D.A. (1990): Absorptive Capacity: A New Perspective on Learning and Innovation, in: Administrative Science Quarterly, 35, 1, 128-152.

Cohen, W.M./Levinthal, D.A. (1994): Fortune Favors the Prepared Firm, in: Management Science, 40, 2, 227-251.

Craig, S.C./Douglas, S.P. (2005): International Marketing Research. Chichester: John Wiley.

Dahlander, L./Gann, D.M. (2010): How Open is Innovation?, in: Research Policy, 39, 6, 699709. 
Damanpour, F. (2010): An Integration of Research Findings of Effects of Firm Size and Market Competition on Product and Process Innovations, in: British Journal of Management, 21, 4, 996-1010.

De Jong, J.P.J./Freel, M. (2010): Absorptive Capacity and the Reach of Collaboration in High Technology Small Firms, in: Research Policy, 39, 1, 47-54.

Diamantopoulos, A./Siguaw, J.A. (2009): Introducing Lisrel. London: Sage Publications.

Dillman, D.A. (2007): Mail and Internet Surveys: The Tailored Design Method. New York: John Wiley \& Sons.

Engelen, A./Heinemann, F./Brettel, M. (2009): Cross-cultural Entrepreneurship Research: Current Status and Framework for Future Studies, in: Journal of International Entrepreneurship, 7, 3, 163-189.

Escribano, A./Fosfuri, A./Tribó, J.A. (2009): Managing External Knowledge Flows: The Moderating Role of Absorptive Capacity, in: Research Policy, 38, 1, 96-105.

Foo, M.D./Uy, M.A./Baron, R.A. (2009): How Do Feelings Influence Effort? An Empirical Study of Entrepreneurs' Affect and Venture Effort, in: Journal of Applied Psychology, 94, 4, 1086-1094.

Fornell, C./Larcker, D.F. (1981): Evaluating Structural Equation Models with Unobservable Variables and Measurement Error, in: Journal of Marketing Research, 18, 1, 39-50.

Granovetter, M.S. (1973): The Strength of Weak Ties, in: American Journal of Sociology, 78, $6,1360-1380$.

Greve, A. (1995): Networks and Entrepreneurship - An Analysis of Social Relations, Occupational Background, and Use of Contacts during the Establishment Process, in: Scandinavian Journal of Management, 11, 1, 1-24.

Greve, A./Salaff, J.W. (2003): Social Networks and Entrepreneurship, in: Entrepreneurship Theory \& Practice, 28, 1, 1-22.

Havnes, P.-A./Senneseth, K. (2001): A Panel Study of Firm Growth among Smes in Networks, in: Small Business Economics, 16, 4, 293-302.

Hervas-Oliver, J.-L. et al. (2012): The Role of a Firm's Absorptive Capacity and the Technology Transfer Process in Clusters: How Effective are Technology Centres in Low-Tech Clusters?, in: Entrepreneurship and Regional Development, 24, 7-8, 523-559.

Hmieleski, K.M./Corbett, A.C. (2008): The Contrasting Interaction Effects of Improvisational Behaviour with Entrepreneurial Self-Efficacy on New Venture Performance and Entrepreneur Work Satisfaction, in: Journal of Business Venturing, 23, 4, 482-496.

Huang, H.-C./Lai, M.-C./Lo, K.-W. (2012): Do Founders' Own Resources Matter? The Influence of Business Networks on Start-Up Innovation and Performance, in: Technovation, 32, 5, 316-327.

Jiménez-Jiménez, D./Sanz-Valle, R. (2011): Innovation, Organizational Learning, and Performance, in: Journal of Business Research, 64, 1, 408-417.

Jansen, J.J.P./Van Den Bosch, F.A.J./Volberda, H.W. (2005): Managing Potential and Realized Absorptive Capacity: How Do Organizational Antecedents Matter?, in: Academy of Management Journal, 48, 6, 999-1015. 
Jones, M. V. et al. (2009): Internationalization, Entrepreneurship and the Smaller Firm: Evidence from Around the World. Cheltenham: Edward Elgar Publishing.

Jørgensen, F./Ulhøi, J.P. (2010): Enhancing Innovation Capacity in SMEs through Early Network Relationships, in: Creativity and Innovation Management, 19, 4, 397-404.

Julien, P.A./Andriambeloson, E./Ramangalahy, C. (2004): Networks, Weak Signals and Technological Innovations among Smes in the Land-Based Transportation Equipment Sector, in: Entrepreneurship and Regional Development, 16, 4, 251-269.

Kariv, D. et al. (2009): Transnational Networking and Business Performance: Ethnic entrepreneurs in Canada, in: Entrepreneurship and Regional Development, 21, 3, 239-264.

Kickul, J./Walters, J. (2002): Recognizing New Opportunities and Innovations: The Role of Strategic Orientation and Proactivity in Internet Firms, in: International Journal of Entrepreneurial Behaviour and Research, 8, 6, 292-308.

Klyver, K./Hindle, K./Meyer, D. (2008): Influence of Social Network Structure on Entrepreneurship Participation - A Study of 20 National Cultures, in: International Entrepreneurship and Management Journal, 4, 3, 331-347.

Kotabe, M./Jiang, C.X./Murray, J.Y. (2011): Managerial Ties, Knowledge Acquisition, Realized Absorptive Capacity and New Product Market Performance of Emerging Multinational Companies: A Case of China, in: Journal of World Business, 46, 2, 166-176.

Kraft, K. (1990): Are Product- and Process-Innovations Independent of Each Other?, in: Applied Economics, 22, 8, 1029-1038.

Lasagni, A. (2012): How can External Relationships Enhance Innovation in Smes? New Evidence for Europe, in: Journal of Small Business Management, 50, 2, 310-339.

Lechner, C./Dowling, M./Welpe, I. (2006): Firm Networks and Firm Development: The Role of the Relational Mix, in: Journal of Business Venturing, 21, 4, 514-540.

Lee, D.Y../Tsang, E.W.K. (2001): The Effects of Entrepreneurial Personality, Background and Network Activities on Venture Growth, in: Journal of Management Studies, 38, 4, 583-602.

Leick, B. (2011): Barriers to Co-Operation and Competitive Advantage: Cross-Border Business Networks of Saxon and Northern Bohemian Firms, in: Journal for East European management studies, 16, 2, 162-184.

Lenox, M./King, A. (2004): Prospects for Developing Absorptive Capacity Through Internal Information Provision, in: Strategic Management Journal, 25, 4, 331-345.

Libby, R./Luft, J. (1993). Determinants of Judgment Performance in Accounting Settings: Ability, Knowledge, Motivation, and Environment, in: Accounting, Organizations and Society, 18, 5, 425-450.

Manolova, T.S./Manev, I.M./Gyoshev, B.S. (2010): In Good Company: The Role of Personal and Inter-Firm Networks for New-Venture Internationalization in a Transition Economy, in: Journal of World Business, 45, 3, 257-265.

Molina-Morales, F.X./Mas-Verdu, F. (2008): Intended Ties with Local Institutions as Factors in Innovation: An Application to Spanish Manufacturing Firms, in: European Planning Studies, 16, 6, 811-827. 
Murovec, N./Prodan, I. (2009): Absorptive Capacity, Its Determinants, and Influence on Innovation Output: Cross-Cultural Validation of the Structural Model, in: Technovation, $29,12,859-872$.

Muscio, A. (2007): The Impact of Absorptive Capacity on Smes'Collaboration, in: Economics of Innovation and New Technology, 16, 8, 653-668.

Nieto, M.J./Santamaria, L. (2010): Technological Collaboration: Bridging the Innovation Gap between Small and Large Firms, in: Journal of Small Business Management, 48, 1, 44-69.

North, D./Smallbone, D. (2000): Innovative Activity in Smes and Rural Economic Development: Some Evidence from England, in: European Planning Studies, 8, 1, 87-106.

O'Reilly Iii, C.A./Chatman, J.A. (1994): Working Smarter and Harder: A Longitudinal Study of Managerial Success, in: Administrative Science Quarterly, 39, 603-627.

Ornaghi, C. (2006): Spillovers in Product and Process Innovation: Evidence from Manufacturing Firms, in: International Journal of Industrial Organization, 24, 2, 349-380.

Parisi, M.L./Schiantarelli, F./Sembenelli, A. (2006): Productivity, Innovation and R\&D: Micro Evidence for Italy, in: European Economic Review, 50, 8, 2037-2061.

Pinkse, J./Kuss, M.J./Hoffmann, V.H. (2010): On the Implementation of a "Global" Environmental Strategy: The Role of Absorptive Capacity, in: International Business Review, $19,2,160-177$.

Podsakoff, P. M. et al. (2003): Common Method Biases in Behavioural Research: A Critical Review of the Literature and Recommended Remedies, in: Journal of Applied Psychology, 88, 5, 879-903.

Prodan, I./Drnovšek, M. (2010): Conceptualizing Academic-Entrepreneurial Intentions: An Empirical Test, in: Technovation, 30, 5-6, 332-347.

Rammer, C./Czarnitzki, D./Spielkamp, A. (2009): Innovation Success of Non-R\&DPerformers: Substituting Technology by Management in SMEs, in: Small Business Economics, 33, 1, 35-58.

Renzulli, L.A./Aldrich, H./Moody, J. (2000): Family Matters: Gender, Networks, and Entrepreneurial Outcomes, in: Social forces, 79, 2, 523-546.

Shan, W./Walker, G./Kogut, B. (1994): Interfirm Cooperation and Startup Innovation in the Biotechnology Industry, in: Strategic Management Journal, 15, 5, 387-394.

Spithoven, A./Clarysse, B./Knockaert, M. (2010): Building Absorptive Capacity to Organise Inbound Open Innovation in Traditional Industries, in: Technovation, 30, 2, 130-141.

Tomlinson, P.R. (2010): Co-operative Ties and Innovation: Some New Evidence for UK Manufacturing, in: Research Policy, 39, 6, 762-775.

Volberda, H./Foss, N./Lyles, M. (2010): Absorbing the Concept of Absorptive Capacity: How to Realize its Potential in the Organization Field, in: Organization Science, 21, 4, 931951.

Wang, C./Han, Y. (2011): Linking Properties of Knowledge with Innovation Performance: The Moderate Role of Absorptive Capacity, in: Journal of Knowledge Management $15,5,802-819$. 
Watson, J. (2007): Modeling the Relationship between Networking and Firm Performance, in: Journal of Business Venturing, 22, 6, 852-874.

Witt, P. (2004): Entrepreneurs' Networks and the Success of Start-Ups, in: Entrepreneurship and Regional Development, 16, 5, 391-412.

Xiang-Yang, Z./Frese, M./Giardini, A. (2010): Business Owners' Network Size and Business Growth in China: The Role of Comprehensive Social Competency, in: Entrepreneurship and Regional Development, 22, 7/8, 675-705.

Yang, M.-L./Wang, A.M.-L./Cheng, K.-C. (2009): The Impact of Quality of IS Information and Budget Slack on Innovation Performance, in: Technovation, 29, 8, 527-536.

Zahra, S.A./George, G. (2002): Absorptive Capacity: A Review, Reconceptualization, and Extension, in: Academy of Management Review, 27, 2, 185-203.

Zahra, S.A./Hayton, J.C. (2008): The Effect of International Venturing on Firm Performance: The Moderating Influence Of Absorptive Capacity, in: Journal of Business Venturing, 23, 2, 917-955.

Zhou, L./Wu, W./Luo, X. (2007): Internationalization and the Performance of Born-Global SMEs: The mediating role of social networks, in: Journal of International Business Studies, 38, 4, 673-690. 